Molnár Benedek

ELTE ÁJK Polgári Jogi Tanszék

Témavezető: Balogh Zsolt György egyetemi docens, BCE

Gazdálkodástudományi Kar, Infokommunikációs Tanszék

DOI: $10.55052 /$ themis. 2021.2.37.63

\title{
A jogi szolgáltatói szektor helyzete a koronavírus járványt megelőzően és a pandémia alatt
}

Az alábbi tanulmányban arra törekszem, hogy bemutassam a jogi szolgáltatói szektor helyzetét a koronavírus válságot megelőző időszakban, és röviden ismertessem a pandémia jogi szolgáltatói szektorra gyakorolt hatását. Az elemzés középpontjában az Egyesült Államok és az Egyesült Királyság B2B jogi piacai állnak, ezen belül elsődlegesen a "Biglaw" ügyvédi irodákat érintő trendeket mutatom be, kitekintve a legaltech szektorra és az alternatív jogi szolgáltatói szegmensre is. Az utóbbi két szegmens egyre növekvő ütemben fejlődött az elmúlt évtizedben, ugyanakkor a COVID-19 pandémia és az ennek hatására kibontakozó gazdasági válság rávilágított azokra a problémákra és kihívásokra, amelyeket ezek az új piaci szereplők már évek óta próbálnak megoldani.

Az első fejezetben a vizsgálódás kereteit és a használt módszertant rögzítem. Ezt követően áttekintem a szektor helyzetét a koronavírust megelőző időszakban (2019 végéig), majd ismertetem a legjelentősebb kihívásokat, amelyet a jogi piac szereplőinek szembesülnie kellett a pandémia következtében.

\section{Az elemzés keretei}

A jogi szolgáltatási piac nagyságának meghatározására többféle becslés létezik, melyek között 5-10 százalékos eltérést láthatunk. Ezt figyelembe véve a jogi szolgáltatások piaca globális szinten hozzávetőlegesen 713,7 milliárd dollárt tett ki 2020-ban ${ }^{1}$, a piac mérete egyes becslések szerint

\footnotetext{
${ }^{1}$ Business Wire, '\$713+ Billion Legal Services Global Market to 2030’,
} 
2021-ben a 750 milliárd dollárt is elérheti ${ }^{2}$. A teljes szektort B2B (business-to-business), B2C (business-to-consumer), hibrid és büntetőjogi szegmensekre oszthatjuk ${ }^{3}$. Ebből a két legnagyobb szegmens a B2B (nagyságrendileg 402 millárd dollár 2020-ban ${ }^{4}$ ) és a B2C (megközelítőleg 136 milliárd dollár 2020-ban ${ }^{5}$ ).

A fenti arányokból láthatjuk, hogy a szektoron belül a B2B szegmens a meghatározó, ezért elemzésünkben is erre a szegmensre fogunk fókuszálni. Emellett a B2C szegmensen belül tapasztalható kihívások (pl. a joghoz való hozzáférés, az "access to justice" kérdése ${ }^{6}$ ), a piaci szereplők helyzete és az őket hajtó üzleti szempontok jelentősen eltérnek, ezért a B2C szegmens vizsgálata meghaladná jelen tanulmány kereteit. A B2B szegmensen belül a vevők jellemzően mikro-, kis- és középvállalkozások, valamint nemzeti és multinacionális nagyvállalatok, az eladók pedig ügyvédi irodák. Az ügyvédi irodák közül kiemelkednek az úgynevezett "Biglaw" irodák, amelyek mind a piaci részesedés, a munkavállalók száma és a bevétel szempontjából domináns szereplőknek számítanak, ezért őket helyezem a vizsgálódás középpontjába. Biglaw irodák alatt azokat ügyvédi irodákat értjük, amelyek (i) legalább 101 ügyvéddel dolgoznak, (ii) az ügyvédek legalább 160.000 dollárt keresnek évente, (iii) és az irodák jellemzően nem magánszemélyeket, hanem nagyvállalatokat képviselnek?

A tanulmányban az Egyesült Államokban és az Egyesült Királyságban zajló piaci folyamatokat fogom vizsgálni a következő négy ok miatt. Először is, ez a két ország a meghatározó az észak-amerikai és nyugateurópai régióban, ami a teljes jogi szolgáltatói piac 56 és 24 százalékát teszi $\mathrm{ki}^{8}$. Ezzel összefüggésben a globálisan működő Biglaw irodák is

https://www.businesswire.com/news/home/20210705005179/en/713-Billion-Legal-Services-Global-Market-to2030---Identify-Growth-Opportunities-for-Investment---ResearchAndMarkets.com (2021.11.14.)

Statista Reseach Department, 'Size of the global legal services market 2020'., https://www.statista.com/statistics/605125/size-of-the-global-legal-services-market/ (2021.11.14.)

${ }^{3}$ Research and Markets: 'Global Legal Services Markets, 2021-2030: B2B Legal Services, B2C Legal Services, Hybrid Legal Services, \& Criminal Law Practices', https://www.prnewswire.com/newsreleases/global-legal-services-markets-2021-2030-b2b-legal-services-b2c-legal-services-hybrid-legal-services-criminal-law-practices-301222994.html (2021.11.15.)

${ }^{4}$ Research and Markets, 'Global B2B Legal Services Market Report 2021: Focus on Corporations; Government Institutions; Small and Medium-sized Enterprises; High Net Worth Individuals', https://www.prnewswire.com/news-releases/global-b2b-legal-services-market-report-2021-focus-oncorporations-government-institutions-small-and-medium-sized-enterprises-high-net-worth-individuals301325081.html (2021.11.14)

Business Wire: 'Insights on the B2C Legal Services Global Market to 2027', https://www.businesswire.com/news/home/20210218005783/en/Insights-on-the-B2C-Legal-Services-GlobalMarket-to-2027---Featuring-Baker-McKenzie-Clifford-Chance-and-DLA-Piper-International-Among-Others--ResearchAndMarkets.com (2021.11.15.)

${ }^{6}$ Cohen 2020a.

7 Top Law Schools, An Introduction to "Biglaw", https://www.top-law-schools.com/introduction-tobiglaw.html, (2021.11.15.)

${ }^{8}$ LAW.COM, Global Legal Services Market (2020 to 2030) - Opportunities and Strategies with COVID-19 Impact and Recovery, https://www.law.com/legalnewswire/news.php?id=2890258 (2021.11.17.) 
ezekben az országokban bírnak székhellyel - az Egyesült Államok a két ország közül is kiemelkedik, ugyanis egy 2020-as felmérés szerint, amely bevétel alapján rangsorolta a legnagyobb ügyvédi irodákat, a 100 legnagyobb ügyvédi iroda háromnegyedének az USA-ban van a székhelye ${ }^{9}$. Harmadrészt mind a legaltech, mind az alternatív jogi szolgáltatók is ezekben az országokban rendelkeznek a legnagyobb ügyfélkörrel. Végül pedig ezekben az országokban állnak rendelkezésre olyan adatok és tanulmányok, amelyek alapján a meghatározó piaci folyamatok leírhatóak. Ezekben az országokban az ügyvédi irodák pénzügyi teljesítménye a nyilvános beszámolóik alapján transzparens, míg sajnálatos módon Magyarországon jelenleg ezek az adatok nem hozzáférhetőek, ugyanis egyedül 2015-ben állított fel és vont is vissza sebtében erre vonatkozó kötelezettséget a jogalkotó ${ }^{10}$.

A Biglaw irodákra a tanulmányban "tradicionális szolgáltatóként" fogok hivatkozni, mikor szembeálítom őket a legaltech és alternatív jogi szolgáltatókkal. Ahogy 2.2 és 2.3 fejezetekben látni fogjuk, a legaltech és alternatív jogi szolgáltatók piaci részesedése eltörpül a Biglaw irodák részesedéséhez képest, ezzel együtt jelentőségüket az adja, hogy létrejöttüket azok a tradicionális jogi szolgáltatói szektorban tapasztalható kihívások ösztönözték, amely kihívásokat a koronavírus járvány még inkább felerősített.

A legaltech szektor meghatározására a Christian Lang által megalkotott, tág definíciót használom. Eszerint a legaltech "(1) olyan technológia, amely elősegíti jogi szolgáltatásnyújtást az ügyvédek számára és (2) olyan technológia, amely segíti a fogyasztókat, hogy jogi szaktudáshoz vagy igazságszolgáltatáshoz férjenek hozzá"ll. A tradicionális szolgáltatói szektornál tett megszorításhoz hasonlóan a definíció második pontja nem képezi a vizsgálat tárgyát, mert az elsődlegesen a B2C szegmenst érinti, ezért jelen tanulmányban az első ponttal fogok dolgozni. Ebbe az első kategóriába beletartoznak egyrészt azok a mára mindennapossá és nélkülözhetetlenné vált megoldások, amelyeket már nagyjából három évtizede alkalmaznak jogászok, mint például szerződés draftoló, ügyviteli szoftverek (óradíj számításra szolgáló időmérő "time-keeping" megoldások, számlázó programok) és a jogi adatbázisok. Ezeknek a jelentőségét nem szabad alábecsülni, mert ahogy Lang fogalmaz "nem túl eredeti, ennek ellenére az az igazság, hogy az ügyvédek számára a legfontosabb legaltech megoldások a Microsoft Word és az email"12. Szintén

\footnotetext{
${ }^{9}$ Zaretsky 2021.

${ }^{10}$ Lándori 2015.

${ }^{11}$ Lang 2018.

12 Uo.
} 
e megoldások közé tartoznak azok az eszközök, amelyek az ügyvédek és ügyfeleik közötti biztonságos, online kommunikációt teszik lehetővé, olyan platformok, amelyek felhő alapú, távoli elérést biztosítanak a dokumentumokhoz - két olyan terület, amelyre a 3. fejezetben külön is kitérek. Ugyanis ezek a technológiai megoldások segítették a jogi piac szereplőit abban, hogy a koronavírus járvány miatt kötelezően elrendelt, vagy önként vállalt távmunka során a szolgáltatásnyújtás folytonosságát biztosítani tudják. Emellett természetesen idetartoznak azok a technológiai megoldások is, amelyek az elmúlt években a legaltech szereplőkkel kapcsolatban a szakmai érdeklődés középpontjában álltak, mint például a mesterséges intelligenciára épülő szerződés draftoló, a jogi kutatás vagy átvilágítás esetén használt szoftverek.

Az alternatív jogi szolgáltatók ("Alternative Legal Service Providers" vagy "ALSP") alatt pedig olyan szervezeteket értünk, amelyek "alternatívát jelentenek a tradicionális megoldáshoz képest, amelynek keretében egy ügyvédi irodában dolgozó ügyvédet bíznak meg annak érdekében, hogy egy jogi ügy megoldásában teljeskörü segítséget nyújtson"13, és amelyek egy vagy több olyan szolgáltatást nyújtanak, amelyeket hagyományosan ügyvédi iroda nyújtana. ${ }^{14}$ Fontos megjegyezni továbbá, hogy ugyan maga a szakmában elfogadott ALSP elnevezés is tartalmazza az "alternatív" kifejezést, itt nem maga a jogi szolgáltatás számít alternatívnak, vagy tér el lényegesen az ügyvédi irodák által nyújtott szolgáltatásoktól, hanem sokkal inkább a szervezeti keret, amelyben az ALSP-k működnek, illetve a munkaszervezési módszerek és technológiák, amelyeket alkalmaznak.

Végezetül fontos rögzíteni, hogy ugyan a koronavírus járvány okozta egészségügyi és gazdasági válság hatására az üzleti élet (köztük a jogi piac) szereplőinek is számos új szabályozásnak kell megfelelniük, ezeket a szabályokat külön nem vizsgálom. Ehelyett a jogi szolgáltatói szektort üzleti fókuszú kérdések mentén tekintem át.

\section{Belle Époque - a jogi szolgáltatói szektor a COVID-19 járványt megelőzően}

A jogi piac transzformációja, a legaltech és alternatív jogi szolgáltatók folyamatos és egyre gyorsuló ütemű térhódítása, valamint az új szereplők

\footnotetext{
13 Thomson Reuters, 2017. p.1.

14 ParalegalEdu.org, 'Paralegals Benefit From the Rise of Alternative Legal Service Provider (ALSP) Companies_, https://www.paralegaledu.org/alternative-legal-service-providers/ (2021.11.17)
} 
hatása a jogi szektorra az elmúlt évtized meghatározó témái voltak a jogász szakma jövőjéről folytatott üzleti és akadémiai diskurzusnak. Ez a gondolkodás szerencsére mára már elmozdult abból az irányból, ami az évtized elején még jellemző volt, amikor a szalagcímek azokról a robotjogászokról harsogtak, akik megtisztítják a jogász szakmát az ügyvédek mohóságától.

Abban ugyanakkor mind az akadémiai, mind az üzleti szféra szereplői egyetértenek, hogy a jogászi szakma soha nem látott átalakulás előtt áll, és hogy azok a szolgáltatók, amelyek nem képesek alkalmazkodni a változásokhoz, nem tudnak belépni a szép új (jogi) világba. Ebben a fejezetben azt tekintem át, hogy a szektor szereplőire milyen pozícióban sújtott le a pandémia.

\subsection{Tradicionális szolgáltatók}

A 2020-ban kezdődő koronavírus-válsághoz hasonló kihívásokkal utoljára a 2008-as gazdasági válság idején kellett szembenézniük az ügyvédi irodáknak. E válság következtében honosodott meg a piacon a "többet kevesebbért" („more for less") doktrína ${ }^{15}$. Ennek alapján az ügyfelek magasabb értékű jogi szolgáltatást kezdtek elvárni az ügyvédi irodáktól alacsonyabb árakért, annak érdekében, hogy tudják tartania cégeik költségvetési megszorításait.

A "more for less" jelenség növekvő szerepe ellenére az elmúlt évtizedben folyamatosan nőttek a jogi szolgáltatásokra fordított ügyfélköltések, és az Egyesült Államokban és az Egyesült Királyságban működő Biglaw irodák nagyjából szinten tartották a válságot megelőző profitabilitásukat (35 és 40 százalék közötti profitrátával müködve). Ugyanakkor a szektorban tapasztalható többletköltés nem ezeknél az irodáknál csapódott le, hanem az alábbi szereplőknél:

a) nagyvállaltok jogi osztályai (amelyek egyben vevői és versenytársai is az ügyvédi irodáknak),

b) legaltech cégek, és

c) alternatív jogi szolgáltatók ${ }^{16}$.

A tradicionális jogi szolgáltatói szektor - a méretéből és a többékevésbé érintetlen profitabilitásából fakadóan - a leglassabban reagált az ügyfelek válságot követő új elvárásaira. Ezzel együtt, a Georgetown Law

\footnotetext{
${ }^{15}$ Susskind 2013. 4-5.

${ }^{16}$ Georgetown Law et.al. 201815.
} 
és Thomson Reuters közös kutatása alapján ugyan később és lassabban, de az ügyvédi irodák is hozzáláttak újszerü stratégiák implementálásához (mint például legaltech eszközök bevezetése, szervezeti átalakítások, ALSP-k leányvállalatként történő alapítása vagy ilyen szolgáltatókkal együttműködések kialakítása), ami segítette őket abban, hogy a változó piaci és ügyféligényekre megfelelően tudjanak reagálni ${ }^{17}$.

Ez az alkalmazkodás döntően hozzájárulhatott ahhoz, hogy 2018-ban tíz éves csúcsra érjen az "Am Law 200” irodák (bruttó bevétel alapján az Egyesült Államok 200 legnagyobb ügyvédi irodája) pénzügyi teljesítménye az Egyesült Államokban ${ }^{18}$. Az Egyesült Királyságban a PWC "Law Firm Survey Report"-ja szerint a 100 legnagyobb ügyvédi iroda 91 százaléka ugyan átlagosan 8,3 százalékos növekedést ért el az árbevétel tekintetében, ugyanakkor a profitabilitásuk elmarad az USA-ban működő irodákhoz képest, mivel az átlag a 2014-es 40 százalékról 36,6 százalékra esett 2018-ban.

Az Am Law 200 2019-es pénzügyi eredménye nem volt olyan meggyőző, mint a megelőző évben, de ezek az irodák így is átlagosan 5,3 százalékos árbevétel növekedésről számoltak be. Ugyanebben az évben az Egyesült Királyság teljes jogi szolgáltatói piacát (amelybe beletartoznak az egyéni ügyvédek, a „barrister"-ek, a szabadalmi ügyvivők, valamint az alternatív és legaltech szolgáltatók is) 37 milliárd fontra becsülték ${ }^{19}$. A UKban a száz legnagyobb ügyvédi iroda árbevételének növekedése folytatódott az előző évhez képest (átlagosan 5,9 százalékkal), de a profitrátájuk csökkenése nem állt meg, ami további 1,1 százalékkal 35,5 százalékra esett ${ }^{20}$.

Mivel a fentiek piaci átlagokat jelentenek, fontos megjegyezni, hogy hasonlóképpen ahhoz, ahogy a Biglaw irodák aránytalanul nagy piaci részesedéssel bírnak azokhoz az irodákhoz képest, amelyek mikrovállalkozásokat és magánszemélyeket szolgálnak ki, úgy az Am Law 200-ba tartozó irodák esetében is aránytalanul oszlanak meg az árbevételek. Ugyanis ezen irodák között a teljes árbevétel több mint 50 százalékát a húsz legnagyobb iroda generálja - ami előrevetíti, hogy a

${ }^{17}$ Georgetown Law et.al. 2019.

18 Astor Professional Search, 'Am Law 200: Law Firms Report Best Performance in Over a Decade',https://www.astorsearch.com/2019/06/am-law-200-law-firms-report-best-performance-in-over-adecade/, (2021.11.18.)

${ }^{19}$ Research and Markets, 'United Kingdom Legal Services Industry Report, 2020 - Market Revenue Reaches $£ 37 B n$ in 2019 and Annual Growth of Almost 5\% Forecast for the Next Two Years', https://www.globenewswire.com/news-release/2020/03/11/1998782/0/en/United-Kingdom-Legal-ServicesIndustry-Report-2020-Market-Revenue-Reaches-37Bn-in-2019-and-Annual-Growth-of-Almost-5-Forecast-forthe-Next-Two-Years.html (2021.11.18.)

20 PwC Law Firms' Survey 2019, 'Adapting to a new world', https://www.pwc.co.uk/industries/lawfirms/pwc-law-firms-survey-report-2019.pdf, (2021.11.18.) 
piaci koncentráció, azaz a legnagyobb Biglaw irodák összeolvadása a közeljövőben is folytatódni fog ${ }^{21}$.

Az árbevételek és a profit után nézzük, mennyire sikeresen tudta kielégíteni a tradicionális jogi szolgáltatói szektor a koronavírus-válság előtt az ügyfél elvárásokat! Amikor erről a kérdésről nagyvállalati jogtanácsosokat kérdeztek az Egyesül Államokban, akkor az Am Law 200 irodákat kiemelkedően értékelték, ha az ügyvédi irodák munkájának minőségéről, az irodák reszponzivitásáról vagy szakmai felkészültségéről kellett véleményt adni. Ugyanakkor azt tartják róluk, hogy kevésbé törekszenek a probléma megoldására ("lack solution focus"), és szintén rosszabbul értékelik őket költséghatékonysági szempontból (azaz a jogtanácsosok úgy vélik, hogy az ügyvédi irodák képeseknek kellene lenniük, hogy hatékonyabban végezzék a munkájukat a kiszámlázott díjuk fejében). Messze legrosszabbul pedig akkor teljesítenek az Am Law 200 irodák, amikor a válaszadók az ügyek eredményei alapján minősítették őket (arra a kérdésre válaszolva, hogy "az üzleti vagy jogi eredmény a vártnál jobb vagy rosszabb volt-e" $)^{22}$.

A fenti megállapítások összhangban vannak a Georgetown Law és a Thomson Reuters által közzétett "2020 Report on the State of the Legal Market" c. tanulmány (a továbbiakban "2020 Legal Market Report") állításaival. Eszerint befejeződött az a 2008-as gazdasági válság után kezdődött folyamat, amikor az ügyvéd-ügyfél viszonylatban az ügyfelek átvették az irányítást. Az ügyfelek (szemben a 2008-at megelőző hozzáállásukkal) már nem csak költséghatékonysági szempontokat próbálnak érvényesíteni az irodákkal szemben a fentebb már idézett "more for less" doktrína jegyében, de egyre inkább elvárják a kiszámíthatóságot és azt, hogy az ügyvédi irodák növeljék a munkavégzési hatékonyságukat ${ }^{23}$.

Ez a két példa azt mutatja, hogy ugyan az ügyfelek egyre világosabban kommunikálják üzleti igényeiket, az ügyvédi irodák ezeket az igényeket némiképp mégis máshogy értik és értelmezik. A Wolters Kluwer 2020-ban publikált felmérése, ami 700 jogi szakember álláspontját mutatja be az Egyesült Államokból és az Egyesült Királyságból, arra jutott, hogy míg az ügyvédi irodák az árazást tartják a meghatározó és legfontosabb faktornak a szolgáltató választás során, addig az ügyfelek ezt csupán a negyedik legfontosabb tényezőnek gondolják. Ehelyett az alábbi kompetenciákra helyezik a hangsúlyt (fontossági sorrendben):

\footnotetext{
21 Legal Executive Institue, 'How not to think about the 2020 Am Law 200', https://www.legalexecutiveinstitute.com/am-law-200-averages/ (2021.11.18.)

${ }^{22}$ Firoz Dattu et.al. 2018.

${ }^{23}$ Georgetown Law et.al 2020. 15.o.
} 
1. legaltech eszközök implementálásának képessége a hatékonyságnövelés érdekében, és olyan munkaszervezési folyamatok kialakítása, ami elősegíti a közös munkát;

2. speciális szaktudás azon a területen, ahol az ügyfél legfontosabb jogi kérdései felmerülnek; és

3. partnerség az ügyfelekkel, az üzleti igényeik megértése ${ }^{24}$.

Annak ellenére, hogy a Biglaw irodák reagáltak a leglassabban a 2008as gazdasági válságot követően megváltozott ügyféligényekre, úgy tűnik, hogy piaci méretükből és inkumbens helyzetükből fakadóan várhatóan a közeljövőben is megőrzik domináns szerepüket a jogi piacon. A 2020 Legal Market Report megállapítása szerint ezek a tradicionális jogi szolgáltatók nem csak hajlandóak és képesek az innovációra, hanem sok esetben már utol is tudják érni új versenytársaikat (a legaltech cégeket és az alternatív jogi szolgáltatókat). A tanulmány az alábbi öt területet emeli $\mathrm{ki}$, ahol az ügyvédi irodák megfelelően reagáltak a változó piaci körülményekre ${ }^{25}$ :

1. Együttműködés más szakmák specialistáival: mára a Biglaw irodákban is elmúltak azok az idők, amikor az ügyvédek ezermesterként próbáltak valamennyi szerepet ellátni (pl. HR, marketing, pénzügyek). A legfontosabb fejlemény ezen a területen, hogy egyre több iroda alkalmaz projektmenedzsereket és nevez ki chief operational officer-eket („műveleti igazgató/ működésért felelős felső vezetö"26). Ráadásul ez utóbbi szerepköröket már nem csak a belső működés optimalizálása érdekében hozzák létre, hanem azért, hogy segítsék és felügyeljék az ügyfélprojekteket, valamint az ügyfelek igényeinek teljesülését.

2. Hatékonyabb belső rendszerek: az ügyvédi irodák olyan rendszereket vezettek be, amelyeknek a célja a jogi szolgáltatásnyújtás hatékonyságának növelése, és $a z$, hogy az irodák az árazási stratégiájukat minél inkább az ügyfelek igényeire tudják szabni.

3. Partneri együttmüködések és outsourcing: egyre több iroda jön rá, hogy az alternatív jogi szolgáltatók és legaltech cégek nem csupán versenytársaik lehetnek. Ehelyett együttmüködő partnereket keresnek közülük, annak érdekében, hogy minél több munkát kiszervezhessenek (például e-discovery, a jogi és

\footnotetext{
${ }^{24}$ Wolters Kluwer 2020. 9.

${ }^{25}$ Georgetown Law et.al 2020. 17.

26 Aarenson Consulting, 'CEO, CFO, CTO, mit jelentenek magyarul ezek a röviditések? https://www.aarenson.hu/ceo-coo-cfo-cto-cio-mit-jelentenek-magyarul-ezek-a-roviditesek/ (2021.11.19)
} 
nem jogi vonatkozású kutatások, dokumentumok átvilágítása kapcsán). Ezt a trendet nem csak költségszempontok hajtják, hanem az a felismerés is, hogy az irodáknak sokszor jobban megéri egy-egy speciális vagy niche szaktudást a piacról megvásárolni, mint a saját irodájukon belül felépíteni az ehhez szükséges praxist.

4. Leányvállalatok alapítása joghoz kapcsolódó szolgáltatások nyújtására: az előző pontban említett outsourcing mellett vagy helyett az ügyvédi irodák egyre nagyobb arányban alapítanak leányvállalatokat bizonyos, joghoz kapcsolódó szolgáltatások (pl. lobbi tevékenység és kormányzati kapcsolatok, adó- vagy üzleti tanácsadás, jogszabály-figyelés és compliance) nyújtására. Ezek a cégek az iroda brandje alatt működnek.

5. A technológiai megoldások növekvő használata: a jogi tanácsadás automatizációja eredendően bonyolultabb feladat, mert a szolgáltatásban kiemelt jelentősége van a jogászok személyes szakmai tudásának, és ezt a tudást nagyobb kihívás standardizálható folyamatokra bontani. Ennek ellenére egyre nagyobb arányban használnak az ügyvédi irodák is olyan legaltech megoldásokat, amelyek ebben a folyamatban segítik őket. Sőt, sok ügyvédi iroda már nem csak követni próbálja ezeket a fejleményeket, hanem saját kezdeményezéseket indítanak például a szoftverfejlesztés (mint a Clifford Chance Applied Solutions nevű cége), vagy a legaltech tanácsadás \& inkubáció területén (mint a Dentons a NexLaw Labs elnevezésű vállalkozásával), annak érdekében, hogy technológiai megoldásokkal segíthessék ügyfeleik jogi igényeinek megoldását.

\subsection{A legaltech piac áttekintése}

Az előző fejezetben már kitértem rá, hogy a legaltech megoldások elterjedése a jogi piac átalakulásának az egyik motorja, és hogy a legaltech a tudósok power point prezentációiból már átszivárgott a gyakorló jogászok mindennapjaiba szerte a világon.

A szektor felemelkedését jól illusztrálja a Standford Center for Legal Informatics CodeX nevű kezdeményezése, amelynek célja, hogy összegyűjtse és kategorizálja a legaltech startup-okat ${ }^{27}$. Míg 2017-ben

\footnotetext{
${ }^{27}$ Lowell 2016.
} 
csupán 700 céget listáztak ebben a kategóriában ${ }^{28}$, addig jelen tanulmány írásakor, 2021 novemberében már $1837-$ et $^{29}$, ami négy év alatt több mint két és félszeres növekedést jelent. A szektort a 2010-es évek második felében már a kockázati tőkebefektetők is felfedezték maguknak. A szektorba áramló befektetések nagyságrendje 2018-ban lépte át először az 1 milliárd dolláros küszöböt a Law Geex gyújtése szerint ${ }^{30}$. Ez a friss rekord 2019-ben rögtön meg is dőlt, amikor a legaltech startup-okba fektetett kockázati tőke nagysága már a harmadik negyedév végére meghaladta az 1 milliárd dollárt, ekkor összesen 1,23 milliárd dollár értékben kaptak befektetést ezek a cégek ${ }^{31}$.

A piac nagyságának ilyen gyors ütemű bővülésével párhuzamosan a legaltech szolgáltatókról alkotott kép is megváltozott. Kezdetben ugyanis a technológiára alapuló jogi szolgáltatások az alacsonyabb hozzáadott értékü munkákat célozták meg, hiszen a technológiai megoldások ezen a fejlettségi szinten álltak (pl. egyszerü döntési fa logikai modellen alapuló dokumentumszerkesztő programok). Ezek a szolgáltatások lehetővé tették, hogy bizonyos mindennap előforduló, repetitív feladatokat, amelyeket korábban gyakornokok, ügyvédjelöltek vagy jogi asszisztensek és titkárnők végeztek, felváltsanak olyan szoftverekkel, amelyek újak, olcsóbbak, egyszerübbek és könnyen használhatóak voltak. Az új technológiai megoldások korlátai azonban nem tették lehetővé, hogy komplexebb feladatokat is ellássanak a segítségükkel. Ezért ezeket a fejlesztéseket nem nézték jó szemmel a piacon jó beágyazottsággal rendelkező ügyvédi irodák, mert úgy láttak, hogy ezek a szolgáltatások a piac alacsonyabb szegmensét célozzák meg. Úgy vélték, ezért nem tudják a szokásos profitrátával értékesíteni a hagyományos jogi tanácsadói munkájukat. Erre a megközelítésre csak ráerősített az irodák rendkívül konzervatív hozzáállása a technológia használatához ${ }^{32}$.

Ahogy a tradicionális jogi szolgáltatók felismerték a legaltech megoldások használatában rejlő potenciált, és elkezdtek tartani attól, hogy lemaradnak az innovációs versenyben, úgy változtatták meg hozzáállásukat ezekhez a cégekhez. Már a koronavírus válság előtt is azt láthattuk, hogy az ügyvédi irodák nem csak bevezetik ezeknek a szoftvereknek a használatát, hanem stratégiai együttmüködéseket alakítanak ki legaltech cégekkel, vagy jelentős erőforrásokat invesztálnak

${ }^{28}$ A szerző saját gyüjtése 2017-böl

${ }^{29}$ CodeX Techindex, http://techindex.law.stanford.edu/ (

30 Law Geex, 'LegalTech hits $\$ 1$ billion investment as lawyers embrace automation', https://blog.lawgeex.com/legaltech-hits-1-billion-investment-as-lawyers-embrace-automation/ (2021.11.20)

${ }^{31}$ Skolnik 2019.

${ }^{32}$ Hongdao et.al. 2019. 
kutatás-fejlesztési tevékenységre, hogy létrehozhassák saját megoldásaikat ${ }^{33}$.

A legaltech szektor kilátásait a (még a koronavírus előtt) Richard Tromans, az ebben a szegmensben mérvadó Artificial Lawyer nevű portál alapítója foglalta össze. Meglátása szerint a legaltech piacot az alábbi négy trend fogja döntően befolyásolni a következő években ${ }^{34}$

1. Legaltech startupok számának gyorsuló bővülése: mivel a piaci lehetőség és a finanszírozás is adott, ezért várhatóan a következő években is egyre növekvő ütemben lépnek piacra új legaltech startupok.

2. Konszolidáció és a platformok térnyerése: ahogy jelen fejezet elején is említettem, a legaltech startupok száma évről évre gyorsuló ütemben növekszik, ez viszont a korábbi évekkel (20162017) szemben nem jelenti azt, hogy új termék- vagy szolgáltatáskategóriák is ilyen ütemben jelennének meg a piacon. A legaltech startupok növekvő száma megnyitotta a piac szereplői előtt a felvásárlások és egyesülések lehetőségét is, ami az egyes szegmensekben konszolidációt idézett elő. Ez pedig nem csak azt eredményezte, hogy ezeken a területeken nagyobb piaci részesedéssel bírnak ezek az újonnan létrejövő cégek, hanem lehetővé teszi azt is, hogy ezek a szolgáltatók kombinálják szolgáltatásaikat, annak érdekében, hogy az így létrejövő platformokon keresztül minél szélesebb körben tudják ügyfeleik igényeit kiszolgálni.

3. Üzleti inkubátorok növekvő jelentősége: a jogi szektor inkumbens szereplői (ügyvédi irodák, Big4 tanácsadó cégek, kiadók) egyre nagyobb számban alapítanak saját legaltech inkubátorokat, hogy a piacra lépést tervező potenciális új cégekkel már a kezdeti szakaszban partneri együttmüködéseket alakíthassanak ki.

4. Ügyvédi irodák, mint tech szereplők: az ügyvédi irodák kilépnek abból a keretrendszerből, amelyben kizárólag jogi szolgáltatást nyújtanak, és törekedni fognak arra, hogy házon belül saját legaltech fejlesztéseket indítsanak.

33 Thomson Reuters 2019. 17.

34 Tromans 2019. 


\subsection{Alternatív jogi szolgálatói piac}

A legaltech szektorhoz hasonlóan az alternatív jogi szolgáltatói piac is meglehetősen újnak számít, hiszen a kezdetei nagyjából az 1990-es évek elejéig nyúlnak vissza. A szektor úttörői a "legal prcocess outsourcing" („jogi folyamatokat kiszervezo") cégek (a továbbiakban "LPO") voltak, akik arra specializálódtak, hogy az M\&A tranzakciók során feldolgozandó hatalmas mennyiségű dokumentum anyagot az ügyvédi irodákhoz hasonló pontossággal, de jóval alacsonyabb áron dolgozzák fel. Erre azért voltak képesek, mert ezeknél az átvilágításoknál a legtöbb esetben pontosan definiálható szempontok szerint kellett átnézni több ezer vagy több tízezer oldalnyi iratanyagot, és e meghatározott szempontok szerint áttekinthetően rendezni a feltárt lényeges információkat. Az adatok feltárásához nem szükséges kvalifikált és ezért magas óradíjjal dolgozó jogászokat foglalkoztatni, ehelyett elegendő a minőségbiztosításhoz szükséges elveket kidolgozni, és azokat az átvilágítási folyamat során ellenőrizni. Ezzel a jogi munka érdemi része (következtetések levonása, tanácsadás az ügyfélnek) az ügyvédi irodáknál és a jogi osztályoknál maradt, és az LPO-k alapvetően back office (ügyfelekkel közvetlenül nem érintkező, üzletmenetet támogató ${ }^{35}$ ) funkciót láttak $\mathrm{el}^{36}$. A kezdetekben jellemzően nem csak kiszervezték a munkát, hanem olyan külföldi ("offshore") országokban kerestek LPO-kat, ahol a nyelvi és jogi környezet hasonló volt, de munkaerőt nagyságrendekkel olcsóbban lehetett találni, mint például India ${ }^{37}$.

Az LPO modell sikere új szereplőket csábított az ALSP piacra, az elmúlt három évtizedben folyamatosan bővült azoknak szolgáltatásoknak a köre, amelyeket ALSP-k nyújtanak. Az áttekinthetőség érdekében jelen fejezetben a Paralegal.edu által használt definíciót ${ }^{38}$, valamint a Georgetown University 2017-es ALPS tanulmányában alkalmazott, öt osztályra bontott klasszifikációt ${ }^{39}$ alapul véve, az alábbi három kategóriába sorlhatók az ALSP szektor szereplői.

$A z$ 1. fejezetben utaltam arra, hogy ALSP-k az ügyvédi irodákhoz hasonlóan jogi szolgáltatást nyújtanak ügyfeleiknek, de eltérő szervezeti struktúrájuknak és munkaszervezési megoldásaiknak köszönhetően ezt

\footnotetext{
${ }^{35}$ Fordítás forrása: HR Portál, https://www.hrportal.hu/jelentese/back-office.html

${ }^{36}$ Glennie 2012.

${ }^{37}$ Misra 2015.

38 Paralegal EDU.Org, 'Paralegals Benefit From the Rise of Alternative Legal Service Provider (ALSP) Companies', https://www.paralegaledu.org/alternative-legal-service-providers/, (2021.11.22)

${ }^{39}$ Thomson Reuters Legal 2017.
} 

a) alacsonyabb áron (LPO szolgáltatók)
b) rugalmasabban (flexibilis szolgáltatók)
c) integrált szolgáltatás keretében (integrált szolgáltatók)
teszik meg.

\subsubsection{LPO szolgáltatók}

Az LPO-k voltak az első olyan új szereplők a jogi piacon, akik az ügyvédi irodák versenytársaivá (és majd később partnereivé) léptek elő. Jellemzően még mindig olyan munkát végeznek, amely nem igényli tapasztalt jogászok közreműködését. A korábban említett tranzakciós átvilágítási munkák mellett dokumentumelemzést, szabadalmi kutatást is gyakran folytatnak ezek a cégek ${ }^{40}$. Az elmúlt évtizedben megfigyelhető tendencia szerint az LPO cégek is arra törekszenek, hogy egyre magasabb hozzáadott értékü szolgáltatásokat nyújtsanak ügyfeleiknek, mivel az új technológiai megoldások következtében az LPO-k által hagyományos nyújtott dokumentum átvilágítási szolgáltatások egyre inkább a beszállítói lánc részévé ("commodity"-vé) válnak. Ezért elkezdték bővíteni portfoliójukat kockázat-elemző, projekttámogató és mesterséges intelligenciára alapuló szolgáltatásokkal is ${ }^{41}$.

Mivel eredetileg az LPO-kat ügyvédi irodáktól független cégek alapították, ezért válaszul a 2000-es évektől az ügyvédi irodák (pl. Allen\&Overy, Clifford Chance, Eversheds) is elkezdtek LPO szolgáltatókkal együttműködni, illetve megalapítani saját LPO-jukat, amit a szakirodalom "captive $L P O$ "-ként definiál (ez a leányvállalat megfelelője). Ezzel az ügyvédi irodák nem csupán versenyképességüket tudták növelni a piacon, hanem az outsourcinghoz kapcsolódó egyik legnagyobb aggályt, a minőségellenőrzést is házon belül tudták tartani ${ }^{42}$.

Mivel a független LPO-k is egyre magasabb pozíciót igyekeznek kiharcolni maguknak a szolgáltatási értékláncban, ezért "captive" társaikkal folytatott versengésük leginkább a jogász szakemberekért folyt a koronavírus időszak előtt. A független LPO-kat müködtető menedzserek

\footnotetext{
${ }^{40}$ LexisNexis, 'Legal Process Outsourcing: A Billion-Dollar Industry, Complete with Trade Shows, Fierce Competition \& Risks'

https://www.lexisnexis.com/communities/corporatecounselnewsletter/b/newsletter/archive/2014/03/17/legalprocess-outsourcing-a-billion-dollar-industry-complete-with-trade-shows-fierce-competition-amp-risks.aspx $(2021.11 .22)$

${ }^{41}$ McCann 2018

42 Global Legal, 'Captive LPOS for Companies with Significant Offshore Operations' https://globallegal.wordpress.com/2011/04/26/captive-lpos-for-companies-with-significant-offshore-operations/ (2021.11.22)
} 
egyelőre úgy látják, hogy jelenleg még nehezen tudnak versenyezni a Biglaw irodákkal a fizetések és presztízs tekintetében. ${ }^{43}$

\subsubsection{Flexibilis szolgáltatók}

A Thomson Reuters Legal 2017-es ALSP tanulmánya ebbe a körbe sorolja a menedzselt jogi szolgáltatásokat („managed legal services”) és a projekt alapon vagy időszakosan toborzó ("staffing") cégeket. ${ }^{44}$ Az előbbibe azok a szolgáltatók tartoznak, amelyek a jogi osztályoknál rendszeresen felmerülő feladatokra vállalkoznak ${ }^{45}$ úgy, hogy munkájuk során a hatékonyság növelés és számonkérhetőség érdekében nagyban támaszkodnak projektmenedzsment rendszerekre (pl. lean) és folyamatokra, továbbá munkájukat nagyfokú technológiai integráció jellemzi. ${ }^{46} \mathrm{~A}$ második csoportba azok a cégek tartoznak, amelyek az ügyvédi irodák és jogi osztályok időszakos munkaerőigényét elégíti ki úgy, hogy előre meghatározott időtartamra vagy bizonyos projektekre biztosítanak jogász munkaerőt mind alacsony kvalifikációt (pl. dokumentumok átvizsgálása), mind a speciális szaktudást igénylő munkákra. ${ }^{47}$

\subsubsection{Integrált szolgáltatók}

Az ALSP-k utolsó csoportjába azok a vállalkozások tartoznak, amelyek a jogi tanácsadási szolgáltatásukat integrálták meglévő, elsősorban könyvvizsgálatra épülő, de adó- és üzleti tanácsadást is nyújtó vállalkozásukba. Ebben a szegmensben is megtalálhatóak butik tanácsadó cégek és multinacionális vállalatok, de alapvetően a Big4 cégek (Deloitte, EY, KPMG, PWC), a világ négy legnagyobb professzionális tanácsadással foglalkozó vállalata ${ }^{48}$ a meghatározóak. A Big4 cégek világszerte jelentősen növelik a jelenlétüket a jogi piacokon, ami mögött feltehetően az áll, hogy a nagyvállalati ügyfelek egyre inkább olyan globálisan

\footnotetext{
43 Thomson Reuters Legal 2019. 14.

${ }^{44}$ Thomson Reuters Legal 2017.

45 Thomson Reuters Legal 2019.

${ }^{46}$ Nguyen 2020.

47 Thomson Reuters Legal 2019.

${ }^{48}$ Whittaker et.al. 20182.
} 
elérhető megoldásokat keresnek, ahol a jogi szolgáltatásokat további üzleti tanácsadást is tartalmazó keretrendszerben biztosítják ${ }^{49}$.

Emiatt a globális elérés miatt a Big4 tanácsadó cégek könnyebben építhetnek meglévő ügyfélkörükre, akiknek a jogi szolgáltatást a korábban nyújtott üzleti tanácsadás mellé kiajánlhatják, emiatt várhatóan a közeljövőben is növekedni fog a jelentőségük. ${ }^{50}$ A Big4 cégek a Biglaw irodákkal leginkább a szabályozási és compliance kérdésekben, a tranzakciós szolgáltatások nyújtásában, a szerződés draftolásban, valamint peres képviseletben versenyeznek. ${ }^{51}$ Azt a veszélyt, amelyet a Big4 cégek jelentenek a tradicionális jogi szolgáltatói szektorra nézve, Richard Susskind az alábbiak szerint fogalmazta meg: „Egy nagyságrenddel nagyobbak, mint az ügyvédi irodák, emellett sokkal nagyobb befektethető tőkével, jelentősebb technológiai és emberi erőforrás rendszerekkel rendelkeznek, amelyeket szélesebb körben tudnak alkalmazni". ${ }^{52}$

A fenti három kategóriába besorolható alternatív jogi szolgáltatók olyan cégek, amelyek döntő többsége magánkézben működő (nem tőzsdén jegyzett) vállalkozás, tulajdonosi körükben pedig az ügyvédek mellett menedzserek és további szakmák képviselői (pl. könyvelők, fejlesztők) is megtalálhatók. A tulajdonosi szerkezetben lévő eltérés miatt az ALPS-knek (a legaltech cégekhez hasonlóan) lehetőségük van arra, hogy kockázati tőkét vonjanak be a müködésükhöz, illetve növekedésük finanszírozásához, ezért a kockázatvállalási stratégiájuk és növekedési lehetőségeik jelentősen eltérnek az ügyvédi irodáktól, ahol főszabály (és a legtöbb esetben jogszabály) szerint is ügyvédek lehetnek tulajdonosok.

2017-ben a piac méretét a témában készült legátfogóbb, a Thomson Reuters és a Georgetown Law által készített kutatás 10,7 milliárd dollárra becsülte, ami 2015-höz képest, mikor az első ilyen felmérést készítették, éves szinten 12,9 százalékos kumulált éves növekedési rátát jelent. ${ }^{53}$

A globális jogi piac méretéhez képest ez a nagyságrend ugyan még eltörpül, az viszont figyelemreméltó, hogy az ALSP szolgáltatók növekedési üteme jelentősen meghaladta ugyanebben az időszakban az ügyvédi irodák átlagos növekedési ütemét (lásd 2.1. fejezet). A 2019-es tanulmány az alternatív jogi szolgáltatók vonatkozásában három fontos trendet emelt ki:

\footnotetext{
49 David B. Wilkins et.al 20162.

50 Thomson Reuters Legal 2017. 8.

51 Thomson Reuters Legal 20194.

52 Duchesne 2018.

53 Thomson Reuters Legal 2019. 1.
} 
1. Alternatív jogi szolgáltatások népszerüsége tovább fog nőni: a nagyvállalati vezetők 2015-ben 2021-re jósolt alternatív jogi szolgáltató igénybevételi aránya (a tradicionális szolgáltatókhoz viszonyítva) már 2017-ben elérte ezt a szintet. Ennek alapján várhatóan a gyakorlatban sokkal hamarabb kezdik el az ügyfelek igénybe venni ezeket a szolgáltatásokat, mint ahogy arra akár maguk is számítanának.

2. Ügyvédi iroda \& ALSP partnerségek: a legaltech cégekhez hasonlóan (lásd 2.2. fejezet) az ügyvédi irodák az ALSP szolgáltatókkal is igyekeznek együttmüködést kialakítani, vagy megalapítani saját ALSP leányvállalatukat

3. Elmozdulás a magasabb hozzáadott értékű szolgáltatások felé: az a trend is hasonló a legaltech piachoz, ugyanis az ALSP szolgáltatók is egyre inkább képessé válnak arra, hogy komplex szolgáltatásokat nyújtsanak ügyfeleiknek.

Ahogy a fent ismertetett trendekből is látszik, az ügyvédi irodák még küszködnek azzal, hogy kialakítsák a megfelelő stratégiát az ALSP-kel való együttműködésben. Ezt támasztja alá a fentebb idézett, Wolters Kluwer által 2020-ban publikált tanulmány ${ }^{54}$ is, amely szerint annak ellenére, hogy az ALSP szolgáltatók a teljes jogi piac töredékét szolgálják ki jelenleg, mindössze az ügyvédi irodák 24 százaléka gondolja úgy, hogy képes lesz kezelni az ALSP cégek belépését a jogi piacra.

\section{A koronavírus járvány hatása a jogi szektorra}

2020 elején a COVID-19 okozta egészségügyi és gazdasági válság a feje tetejére állította a világot. Már 2020 második felében látszott, hogy a koronavírus következtében a világgazdaságnak békeidőben 150 éve nem látott visszaeséssel kell szembenézni. ${ }^{55}$ Emellett ez a válság nem csak mélyebb, hanem lényegében is más, mint a korábbiak. Mark A. Cohen szerint, amíg az elmúlt három évtized gazdasági válságai (az 1987-es tőzsde krach az Egyesült Államokban, a dot.com lufi a 2000-es évek elején és a 2008-as pénzügyi válság) nem változtatták meg alapvetően a jogász szakmát, a COVID-19-nek erre jó esélye van, ugyanis most egyik napról a másikra kellett reagálnia a szektornak a változásokra ${ }^{56}$.

\footnotetext{
${ }^{54}$ Wolters Kluwer 2020. 6

${ }^{55}$ Wolf 2020.

${ }^{56}$ Cohen 2020b.
} 


\subsection{A tradicionális szolgáltatók}

A koronavírus járvány kapcsán a legnagyobb változást az ügyvédi irodák számára a kötelezően elrendelt vagy önként vállalt távmunka hozta. Ugyan a legtöbb Biglaw irodánál már rendelkezésre álltak azok az eszközök, amelyek biztosítják a dokumentumokhoz való biztonságos távoli hozzáférést és a csapattagok közötti kommunikációt, a home office intézménye hagyományosan távol állt az ügyvédi irodai munkavégzéstől, ezért még a jól kiépített infrastruktúrával rendelkező ügyvédi irodák számára is kihívást jelentett ez az átállás ${ }^{57}$.

Az elmúlt másfél év alapján úgy túnik, hogy az ügyvédek megbarátkoztak a home office lehetőségével. Egy 2020 nyarán készített kutatás szerint, amelyben egy nagy ügyvédi iroda több mint 1000 jogász és nem jogász munkatársát kérdezték, azt találták, hogy a válaszadók 72 százaléka munkaidejének felében akkor is inkább otthonról dolgozna, ha már teljesen megszűnnek az irodába járásra vonatkozó korlátozások. Sőt 10-ből majdnem kilenc munkavállaló mondta azt, hogy a jövőben is minimum heti egy napot home officeban töltene. ${ }^{58}$ Amellett, hogy a munkavállalók számára egyelöre úgy tűnik, hogy pozitív fejlemény a távmunka újdonsült lehetősége, egy szintén 2020-ban, 25 ügyvédi iroda bevonásával végzett kutatás szerint a dolgozók (akik közé beletartoztak mind a munkavállalók, mind a vezetőség) 92 százaléka úgy vélte, hogy a távmunka ellenére képesek voltak az ügyféligényeket megfelelően ellátni. ${ }^{59}$

A szolgáltatásnyújtás terén azt láthatjuk, hogy az ügyvédi irodáknak egyszerre kellett menedzselnie azt a kihívást, hogy bizonyos szektorokban (pl. munkajog, adatvédelem és GDPR, csődeljárások) kifejezetten megnövekedett a kereslet a jogi tanácsadások iránt ${ }^{60}$, viszont átlagosan 56 százalékot esett vissza jogi szolgáltatások iránti kereslet az Egyesült Államokban ${ }^{61} 2020$ első felében. Leginkább ez utóbbi tényező miatt 2020 közepén még úgy látszott, hogy az ügyvédi irodák árbevétele a 2019-es évhez képest átlagosan 15-20 százalékkal fog csökkeni. ${ }^{62}$ Ugyanakkor úgy tűnik, hogy az egyesült államokbeli Biglaw irodák a költségcsökkentési

\footnotetext{
${ }^{57}$ Simmonds 2020.

${ }^{58}$ Seeger 2020.

${ }^{59}$ Loeb Leadership, 'The Legal Industry's Handling of the Disruption Caused by COVID-19', https://static1.squarespace.com/static/5c26b8695b409b7ffc6ca248/t/5ed7fbe8b7a089356dfd20ff/1591213033267 Legal+Industry+Survey+-+May+2020.pdf (2021.11.24)

${ }^{60}$ Jones 2021. 9

${ }^{61}$ Wittenberg 2020.

${ }^{62}$ Kumar 2020.
} 
törekvéseiknek és az állami támogatásoknak köszönhetően 2020-ban is megőrizték profitabilitásukat ${ }^{63}$. Ebből arra következtethetünk, hogy ezek az ügyvédi irodák a korábbi válságokból tanulva a közeljövőben is óvatosabb költségvetéssel fognak dolgozni. Ebből következően csökkenhetik az alulteljesítő jogászok számát, újratárgyalhatják az irodabérleti szerződéseiket, valamint növelhetik az ALSP számára kiszervezett munka arányát ${ }^{64}$.

A Thomson Reuters Institute európai jogi piacról szóló tanulmánya szerint Európát sem hagyta érintetlenül a koronavírus okozta gazdasági recesszió, de 2020-hoz képest már jelentősen javultak a kilátások. Ugyanis amíg 2020 második negyedévében az ügyfelek 38 százaléka mondta, hogy csökkenti a jogi kiadásait, és csak 27 százalékuk jelezte, hogy növelné azt, addig 2021 második negyedévére ez az arány megfordult, és 38 százalékuk már a jogi költségvetésük növelését tervezi, és csupán 19 százalék számol azzal, hogy kevesebb jogi szolgáltatást fog vásárolni ${ }^{65}$.

\subsection{A legaltech piac}

Az előző fejezetben utaltunk arra, hogy a távmunkára való átálláshoz minden ügyvédi irodának szükséges volt bizonyos legaltech megoldásokat bevezetnie. A Wolters Kluwer 2020-ben közzétett tanulmánya alapján az európai ügyvédi irodák 56 százaléka azt állította, hogy növekedett a technológiai megoldások iránti igénye, és közel kétharmaduk úgy tartja, hogy technológiai befektetéseik aránya a pandémiát követően is azonos szinten marad, vagy akár növekedni fog. Ugyanebben a tanulmányban az ügyvédi irodák az alábbi öt területet határozták meg a technológiai igényeik kapcsán kulcsfontosságúnak a legaltech beruházásaik szempontjából:

1. e-aláírások;

2. ülések és távoli szavazások lebonyolítását lehetővé tevő szoftverek;

3. dokumentum- és szerződéskezelő rendszerek;

4. ügyviteli menedzsment eszközök;

5. jogi adatbázisok és az esetjog alapján a peres igények kimenetelét előrejelző szoftverek ${ }^{66}$.

\footnotetext{
63 Jones 2021. 11.

${ }^{64}$ Clay 2020.

65 Thomson Reuters Institute 2021a. 5.

${ }^{66}$ Wolters Kluwer 2020.
} 
A fentieken túl, a távmunkához kapcsolódóan nagyobb szerepe lehet azoknak a compliance megoldásoknak is, amelyek abban segítik az ügyvédi irodákat, hogy megfelelően kezeljék a home office miatt felmerülő adatbiztonsági és titoktartási feladataikat ${ }^{67}$.

A legaltech szcénát pénzügyi szempontból is érintette a járvány, hiszen annak ellenére, hogy a legtöbb legaltech startup-ot kockázati tőkebefektetésen keresztül finanszírozzák, egy gazdasági válság általában ezeket a szereplőket érinti leginkább, hiszen az ügyfelek ilyenkor törekszenek arra, hogy visszafogják az új projektekre irányuló költéseiket. Emiatt szakértők azzal számolnak, hogy a koronavírus járvány lecsengése előtt kissé csökkeni fog a legaltech szektor mérete, és elsősorban azok a szolgáltatók lehetnek ennek az időszaknak a nyertesei, akik valamilyen felhő alapú megoldást kínálnak partnereiknek. ${ }^{68}$ Ezzel összhangban az Egyesült Államokban működő Clio jogi ügyviteli platform által készített átfogú tanulmányban idézik azt a kutatást, amely szerint a szektorba irányuló kockázati tőkebefektetések összege 2020-ban mindössze 500 millió dollár volt, 2021-ben viszont már szeptember 1-jén átlépte az 1 milliárd dolláros küszöböt ${ }^{69}$.

\subsection{Az alternatív jogi szolgáltatók}

Az ALSP szektor a koronavírus járvány alatt - a legaltech cégekhez hasonlóan - két, egymással ellentétes folyamatot éltek át eddig. Egyrészt az ügyfelek (különösen jogi ügyekben, ha maguk is jogászok), kifejezetten kockázatkerülőek. Ez alapvetően a tradicionális szolgáltatóknak kedvez, hiszen ilyenkor az ügyfelek szívesebben dolgoznak olyan céggel, akivel már korábban is volt valamilyen kapcsolatuk. Ezért az ALSP-k azt tapasztalhatták, hogy ugyan a koronavírus járvány következtében szűkebbre szabott költségvetések és a távmunka elöretörése felgyorsította az alternatív jogi szolgáltatások igénybevételét, korántsem minden ügyvédi iroda és jogi osztály hajlandó arra, hogy egy válsághelyzetben új beszállítókkal kezdjen el dolgozni egy-egy, az üzletmenet szempontjából kritikus területen ${ }^{70}$.

A szektor szereplői egyetértenek abban, hogy a távmunka széleskörü elterjedése viszont egyértelmúen pozitív hatással volt az alternatív jogi

\footnotetext{
${ }^{67}$ Out-Law News: 'Digital transformation core to coronavirus recovery'

https://www.pinsentmasons.com/out-law/news/digital-transformation-core-to-coronavirus-recovery (2021.11.24)

${ }^{68}$ Coe 2020.

${ }^{69}$ Clio 2021. 43 .

${ }^{70}$ Hudgins 2020.
} 
szolgáltatókra. Ugyanis a potenciális ügyfelek (elsődlegesen jogi osztályok és ügyvédi irodák) maguk is megtapasztalták, hogy ilyen módon is lehet dolgozni, ezáltal könnyebben megbíznak azokban a szolgáltatásokban, amelyek decentralizált munkaerővel dolgoznak úgy, hogy a munkavégzést is csak virtuálisan felügyelik. ${ }^{71}$ Másik új trend, ami a koronavírus járvány hatására felerősödött, az úgynevezett "nearshoring”, amikor korábban külföldre kiszervezett munkákat már egy adott országon belül is költséghatékonyan ki tudják szervezni, a home officenak köszönhetően, hiszen így jelentős költségeket lehet megspórolni a szolgáltatáson ${ }^{72}$.

Pénzügyi szempontból nehezebb vizsgálni a pandémia hatását a szektorra, ugyanis a Thomson Reuters 2021-ben kiadott ALSP tanulmánya csak a publikációt két évvel megelőző adatokat teszi közzé. Ebből viszont annyi mindenképpen látszik, hogy a szektor növekedése továbbra is gyorsul, ugyanis a 2017-es méréshez képest további 3,2 milliárd dollárral növekedett az ALSP szektor mérete, összesen hozzávetőlegesen 13,9 milliárd dollárra, ami 15 százalékos kumulált éves növekedési rátát jelent. Ez több mint a duplája az Am Law 200 ügyvédi irodák ebben az időszakban mért növekedésének (6,4 százalék). ${ }^{73}$

Összeségében az ALPS szolgáltatók kapcsán úgy tünik, hogy az ügyfeleknél jelentkező költségnyomás abba az irányba billenti őket, hogy olyan megoldásokat keressenek, amelyek az általuk igénybe vett jogi munkák többségénél "elegendő hatékonyságúak”, ezért hajlandóak nem tradicionális szolgáltatókat is megbízni ezekben az ügyekben. ${ }^{74}$ Ezeket a benyomásokat megerősíti a Wolters Kluwer 2021-ben publikált "Future Ready Lawyer" kutatása is, amely szerint 2020-hoz képest a legnagyobb változást az összes általuk vizsgált trend közül az "ALSP-k jelentőségének növekedése" hozta, ugyanis egy év alatt, 68 százalékról 74 százalékra ugrott azoknak az ügyvédi irodáknak és jogi osztályoknak az aránya, akik egyetértettek ezzel az állítással. ${ }^{75}$

\footnotetext{
71 Thomson Reuters Institute 2021b. 21.

72 Georgiou 2020.

${ }^{73}$ Thomson Reuters Institute 2021b. 4.

74 Jones 2021. 16.

${ }^{75}$ Wolters Kluwer 2021. 7.
} 


\section{Felhasznált irodalom}

Aarenson Consulting: CEO, CFO, CTO, mit jelentenek magyarul ezek a rövidítések? 2020. https://www.aarenson.hu/ceo-coo-cfo-cto-cio-mitjelentenek-magyarul-ezek-a-roviditesek/ (2021.11.19.)

Aebra Coe: COVID-19 Could Be Make Or Break For Legal Tech Cos. 2020 https://www.law360.com/articles/1259447 (2021.11.24.)

Astor Professional Search: Am Law 200: Law Firms Report Best Performance in Over a Decade. 2019 https://www.astorsearch.com/2019/06/am-law-200-law-firms-reportbest-performance-in-over-a-decade/ (2021.11.18.)

Business Wire: '\$713+ Billion Legal Services Global Market to 2030. 2021

https://www.businesswire.com/news/home/20210705005179/en/713Billion-Legal-Services-Global-Market-to-2030---Identify-GrowthOpportunities-for-Investment---ResearchAndMarkets.com (2021.11.14.)

Business Wire: Insights on the B2C Legal Services Global Market to 2027. 2021

https://www.businesswire.com/news/home/20210218005783/en/Insights -on-the-B2C-Legal-Services-Global-Market-to-2027---Featuring-BakerMcKenzie-Clifford-Chance-and-DLA-Piper-International-Among-Others--ResearchAndMarkets.com (2021.11.15.)

https://doi.org/10.1016/j.focat.2020.12.006

Christian Lang: What is Legal tech? 2018 https://medium.com/@christianllang/what-is-legal-tech-a6edf69140e7 (2021.11.15.)

Christoper Georgiou - Kate Basset: Assessing the impact of COVID-19 on legal operations. 2020 https://www.ashurst.com/en/innovation/ashurst-advance/assessing-theimpact-of-covid-19-on-legal-operations/ (2021.11.24.)

Clio: Legal Trends Report 2021. https://www.clio.com/wpcontent/uploads/2021/08/2021-Legal-Trends-Report-Oct-26.pdf (2021.11.24.)

CodeX Techindex, $2021 \quad$ http://techindex.law.stanford.edu/ (2021.11.19.) 
Danh Nguyen: The Rise and Rise of Managed Legal Services. 2020 https://www.legalbusinessworld.com/post/2020/01/29/the-rise-and-riseof-managed-legal-services (2021.11.23.)

Daniel S. Wittenberg: The Pandemic's Dramatic Effect on the Business of Law. 2020

https://www.americanbar.org/groups/litigation/publications/litigationnews/business-litigation/the-pandemics-dramatic-effect-the-business-law/ (2021.11.24.)

David B. Wilkins - Maria Jose Esteban: The Reemergence of the Big Four in Law. 2016 https://thepractice.law.harvard.edu/article/thereemergence-of-the-big-four-in-law (2021.11.23.)

Elizabeth Lowell: The Current State and Future Prospects for Legal Technology Adoption. 2016 https://law.stanford.edu/2016/05/17/thecurrent-state-future-prospects-for-legal-tech-adoption (2021.11.19.)

Eric A. Seeger: New Law Firm Polling Suggests Almost Everybody Likes Working at Home. 2020

http://www.altmanweil.com/index.cfm/fa/r.resource detail/oid/4F2E78E109E1-484B-8992-

A2191D426B4B/resource/New Law Firm_Polling Suggests Almost Every body Likes Working at Home.cfm (2021.11.24.)

Firoz Dattu - Aaron Kotok: Largest, Most Pedigreed Firms Underperform on Service Quality Compared to Other Firms. 2018 http://www.law.com/americanlawyer/2018/12/12/large-pedigreed-firmsunderperform-on-service-quality-compared-to-other-firms/ (2021.11.18.)

Georgetown Law, Thomson Reuters Legal Executive Institute: 2018 Report on the State of the Legal Market. 2018 https://www.thomsonreuters.com/en/press-releases/2018/january/2018report-on-the-state-of-the-legal-market-from-georgetown-law-andthomson-reuters-legal-executive-institute.html (2021.11.18.)

Georgetown Law, Thomson Reuters Legal Executive Institute: 2019 Report on the State of the Legal Market. 2019 https://legal.thomsonreuters.com/content/dam/ewpm/documents/legal/en/pdf/reports/leipm.pdf (2021.11.18.)

Georgetown Law, Thomson Reuters Legal Executive Institute: 2020 Report on the State of the Legal Market. 2020 https://images.thomsonreuters.com/Web/TRlegalUS/\%7B169f0d36-6fcd4cc1-bd84-

878b713055cb\%7D 2020 Report on the State of the Legal Market191231.pdf (2021.11.19.) 
Global Legal, 'Captive LPOs for Companies with Significant Offshore Operations', 2011 https://globallegal.wordpress.com/2011/04/26/captiveIpos-for-companies-with-significant-offshore-operations/ (2021.11.22.)

James W. Jones (szerk): 2021 Report on the State of the Legal Market. 2021 https://www.legalexecutiveinstitute.com/state-of-the-legal-market2021/ (2021.11.24.)

James Whittaker - Seth Collins: The Big 4 Accounting firms Everything you need to know'. 2018 https://big4careerlab.com/big-4accounting-firms/ (2021.11.23.)

Kathryn McCann: On borrowed time. 2018 http://www.inhouselawyer.co.uk/mag-feature/on-borrowed-time/ (2021.11.22.)

Law Geex: LegalTech hits $\$ 1$ billion investment as lawyers embrace automation. 2018 https://blog.lawgeex.com/legaltech-hits-1-billioninvestment-as-lawyers-embrace-automation/ (2021.11.20.)

Lándori Tamás: Itt a top 10 magyar ügyvédi iroda - a Horváth és Társai DLA Piper a legnagyobb. 2015

https://jog.mandiner.hu/cikk/20150610 itt a top 10 magyar ugyvedi ir oda a horvath es tarsai dla pipe a legnagyobb (2021.11.19.)

LexisNexis, Legal Process Outsourcing: A Billion-Dollar Industry, Complete with Trade Shows, Fierce Competition \& Risks', 2014 https://www.lexisnexis.com/communities/corporatecounselnewsletter/b/n ewsletter/archive/2014/03/17/legal-process-outsourcing-a-billion-dollarindustry-complete-with-trade-shows-fierce-competition-amp-risks.aspx (2021.11.22.)

Loeb Leadership: The Legal Industry's Handling of the Disruption Caused by COVID-19. 2020

https://static1.squarespace.com/static/5c26b8695b409b7ffc6ca248/t/5ed 7fbe8b7a089356dfd20ff/1591213033267/Legal+Industry+Survey++ May+2020.pdf (2021.11.24.)

Mark A. Cohen: COVID-19 And The Reformation Of Legal Culture. 2020 https://www.forbes.com/sites/markcohen1/2020/04/14/covid-19-andthe-reformation-of-legal-culture/\#610809e5171d (2021.11.24.)

Mark A. Cohen: Vision for 2020: A focus on defending the rule of law. 2020 https://www.abajournal.com/voice/article/2020-vision-focus-ondefending-the-rule-of-law. (2021.11.15.) 
Martin Wolf: How Covid-19 will change the world. 2020 https://www.ft.com/content/9b8223bb-c5e4-4c11-944d-94ff5d33a909 , (2021.11.23.)

Oliver Duchesne: Threats To Traditional Legal Practice: An Interview with Richard Susskind - Part 2. 2018

https://www.priorilegal.com/blog/threats-to-traditional-legal-practice-aninterview-with-richard-susskind-part-2 (2021.11.23.)

PwC Law Firms: Survey 2019, 'Adapting to a new world'. 2019 https://www.pwc.co.uk/industries/law-firms/pwc-law-firms-survey-report2019.pdf (2021.11.18.)

Qian Hongdao -Sughra Bibi -Asif Khan - Lorenzo Ardito - Muhammad Bilawal Khaskheli: Legal Technologies in Action: The Future of the Legal Market in Light of Disruptive Innovations. 2019 https://www.mdpi.com/20711050/11/4/1015?type $=$ check update\&version $=1 .(2021.11 .20$. $)$

https://doi.org/10.3390/su11041015

Out-Law News, Digital transformation core to coronavirus recovery. https://www.pinsentmasons.com/out-law/news/digital-transformationcore-to-coronavirus-recovery (2021.11.24.)

Research and Markets: Global Legal Services Markets, 2021-2030: B2B Legal Services, B2C Legal Services, Hybrid Legal Services, \& Criminal Law Practices. 2021 https://www.prnewswire.com/news-releases/global-legalservices-markets-2021-2030-b2b-legal-services-b2c-legal-serviceshybrid-legal-services--criminal-law-practices-301222994.html (2021.11.15.)

Research and Markets: 'Global B2B Legal Services Market Report 2021: Focus on Corporations; Government Institutions; Small and Medium-sized Enterprises; High Net Worth Individuals', 2021.

https://www.prnewswire.com/news-releases/global-b2b-legal-servicesmarket-report-2021-focus-on-corporations-government-institutions-smalland-medium-sized-enterprises-high-net-worth-individuals301325081.html (2021.11.14.)

Research and Markets: United Kingdom Legal Services Industry Report, 2020 - Market Revenue Reaches $£ 37 \mathrm{Bn}$ in 2019 and Annual Growth of Almost 5\% Forecast for the Next Two Years. 2020. https://www.globenewswire.com/newsrelease/2020/03/11/1998782/0/en/United-Kingdom-Legal-ServicesIndustry-Report-2020-Market-Revenue-Reaches-37Bn-in-2019-and- 
Annual-Growth-of-Almost-5-Forecast-for-the-Next-Two-Years.html (2021.11.18.)

Richard E. Susskind: Tomorrow's lawyers: an introduction to your future. Oxford, Oxford University Press, 2013

Richard Tromans: Four Big Themes Of Legal Tech + Innovation in 2019. 2019 https://www.artificiallawyer.com/2019/08/02/four-big-themes-oflegal-tech-innovation-in-2019/ (2021.11.19.)

Robert Glennie: LPOs - the next level of help. 2012 http://www.journalonline.co.uk/Magazine/57-

11/1011854.aspx\#.XKDDqpgzbIU (2021.11.21.)

Sam Skolnik: Legal Tech Broke Investment Record in 2019 as Sector Matures. 2019 https://news.bloomberglaw.com/us-law-week/biggestlegal-tech-deals-and-developments-of-2019 (2021.11.19.)

Sarvarth Misra: An onshore-offshore LPO delivery model for Europe', 2015 https://s3-eu-west-

1.amazonaws.com/www.globallegalpost.com/lpo/lpo-handbook-201213.pdf (2021. 12. 2. ) 30. o.

Stacy Zaretsky: The Global 100: The Richest Law Firms In The World (2021). 2021 https://abovethelaw.com/2021/09/the-global-100-therichest-law-firms-in-the-world-2021/ (2021.11.15.)

Statista Reseach Department: Size of the global legal services market. 2020., 2021 https://www.statista.com/statistics/605125/size-of-theglobal-legal-services-market/ (2021.11.14.)

Thomas S. Clay: Things will be okay. 2020 http://www.altmanweil.com/index.cfm/fa/r.resource detail/oid/37CB453E -B078-49AA-95F2-CCE0B60D1F83/resource/Things Will Be Okay.cfm (2021.11.24.)

Thomson Reuters Institue: Alternative Legal Service Providers 2021. 2021 https://www.thomsonreuters.com/en-us/posts/legal/alsp-report2021/ (2021.11.24.)

Thomson Reuters Institue: 2021 State of the Legal Market in Europe. 2021 https://www.thomsonreuters.com/en-us/posts/legal/european-legalmarket-report-2021/ (2021.11.24.)

Thomson Reuters Legal: Alternative legal service providers industry report. 2017 https://legal.thomsonreuters.com/en/forms/alternativelegal-service-provider-study-2017 (2021.11.10.) 
Thomson Reuters Legal: Alternative legal service providers 2019. 2019 https://legal.thomsonreuters.com/content/dam/ewp$\mathrm{m} /$ documents/legal/en/pdf/reports/alsp-reportfinal. pdf?cid=9008178\&sfdccampaignid=7011B0000020F6AQAW\&chl=pr ， (2021.11.22.)

Thomson Reuters: Legaltech Startup Report 2019 - A Maturing Market. 2019

https://legalsolutions.thomsonreuters.co.uk/content/dam/openweb/docu ments/pdf/uki-legal-solutions/report/tr-legaltech-startup-report-2019.pdf (2021.11.20.)

Top Law Schools: An Introduction to "Biglaw". 2010 https://www.toplaw-schools.com/introduction-to-biglaw.html (2021.11.15.)

Victoria Hudgins: COVID-19 Pushes More Legal Outsourcing, but Not All ALSPs Will Benefit. 2020

https://www.law.com/legaltechnews/2020/08/13/covid-19-pushes-morelegal-outsourcing-but-not-all-alsps-will-benefit/ (2021.11.24.)

Vivek Kumar: Impact and Opportunities of COVID-19 in the Legal Tech Industry. 2020 https://industrywired.com/impact-and-opportunities-ofcovid-19-in-the-legal-tech-industry/ (2021.11.24.)

Wolters Kluwer - A jövő jogásza kutatás - a teljesítmény mozgatórugói. 2020 forrás: https://wolterskluwer.hu/2020/06/10/a-wolters-kluwer-ajovo-jogasza-2020-felmerese-a-teljesitmeny-mozgatorugoit-vizsgalta-ajogi-szektorban-zajlo-valtozasok-fenyeben/ (2021.11.19.)

Wolters Kluwer - The 2021 Wolters Kluwer Future Ready Lawyer. 2021 https://images.go.wolterskluwer.com/Web/WoltersKluwer/\%7B53280717ca9f-47f5-bff6-

a35e52230ef5\%7D FRL2021 WhitePaper Global FINAL.pdf

(2021.11.24.)

$* * *$

State of the legal market in 2020 - prior and amid the COVID-19 pandemic

Summary

In this paper, we will provide an overview on the state of the legal market in 2020 particularly in the United States and the United Kingdom, focusing 
on the main trends regarding biglaw firms, and taking notes on the development of the legal tech sector and the alternative legal service provider market. These two sectors have been continuously developing during the last couple of years, however, the COVID-19 pandemic and the global economic crisis it caused, highlighted the issues that these providers have been trying to solve for years, therefore we will mainly focus on the already existing and potential consequences of the virus, and its effects on the legal market in general.

In the first chapter, we will establish the framework for this paper, to set out the methodology for our examination. Then we will take a look on the legal market prior to the coronavirus outbreak in early 2020, and then highlight the main issues the legal market had to face and rapidly adopt to, and finally, we will examine how traditional legal service providers and the new players of the market faced this unprecedented global challenge. 